\title{
Extended colostrum feeding for 2 weeks improves growth performance and reduces the susceptibility to diarrhea and pneumonia in neonatal Holstein dairy calves
}

\author{
S. Kargarr, ${ }^{1 *}$ M. Roshan, ${ }^{1}$ S. M. Ghoreishi, ${ }^{1}$ A. Akhlaghi, ${ }^{1}$ M. Kanani, ${ }^{1}$ A. R. Abedi Shams-Abadi, ${ }^{1}$ \\ and M. H. Ghaffari ${ }^{2 *}$ \\ ${ }^{1}$ Department of Animal Science, School of Agriculture, Shiraz University, Shiraz 71441-65186, Iran \\ ${ }^{2}$ Institute of Animal Science, Physiology and Hygiene Unit, University of Bonn, 53115 Bonn, Germany
}

\begin{abstract}
The objective of this study was to determine the effect of partial replacement of whole milk with colostrum on the growth performance and health status of Holstein dairy calves. Neonatal heifer calves $(\mathrm{n}=144$; $2 \mathrm{~d}$ of age; $39.3 \pm 0.82 \mathrm{~kg}$ of body weight, BW; mean $\pm \mathrm{SE}$ ) were assigned randomly to 3 groups with partial replacement of pasteurized whole milk with pasteurized colostrum at $0(\mathrm{C} 0 ; 0 \mathrm{~kg} / \mathrm{d}$ of colostrum $+5 \mathrm{~kg} / \mathrm{d}$ of whole milk), $350 \mathrm{~g}$ (C350; $0.350 \mathrm{~kg} / \mathrm{d}$ of colostrum + $4.650 \mathrm{~kg} / \mathrm{d}$ of whole milk), or $700 \mathrm{~g}(\mathrm{C} 700 ; 0.700 \mathrm{~kg} / \mathrm{d}$ of colostrum $+4.300 \mathrm{~kg} / \mathrm{d}$ of whole milk) for $14 \mathrm{~d}$; there were no refusals of liquid feed. From d 15 onward, the calves were fed with $5 \mathrm{~kg} / \mathrm{d}$ of pasteurized whole milk, weaned on d 61, and monitored until d 81 of life. Throughout the study, the calves had free access to fresh clean water and calf starter. Partial replacement of whole milk with colostrum increased liquid feed dry matter intake (DMI) but decreased milk DMI; however, intakes of starter DMI, total DMI, metabolizable energy, crude protein, and ether extract were not affected by treatments. Overall, the C700 calves recorded greater weaning weight, final BW, heart girth change, feed efficiency, and average daily gain (ADG). The calves fed milk had a higher chance of having rectal temperature $\geq 39.4^{\circ} \mathrm{C}$ and general appearance score $\geq 2$ compared with those receiving colostrum in their milk. Diarrhea was more prevalent in C0 versus C700 calves. The occurrence of pneumonia tended to be higher in milk-fed calves compared with C350 and C700 animals. Colostrum feeding resulted in fewer days with a rectal temperature $\geq 39.4^{\circ} \mathrm{C}$, general appearance $\geq 2$, diarrhea, and pneumonia. We computed Cliff's delta (effect sizes)
\end{abstract}

\footnotetext{
Received February 12, 2020.

Accepted May 7, 2020.

*Corresponding authors: skargar@shirazu.ac.ir and morteza1@uni -bonn.de
}

of the extended colostrum feeding (C350 vs. C0, C700 vs. $\mathrm{C} 0$, and $\mathrm{C} 700$ vs. C350) on starter and milk DMI, ADG, BW, and feed efficiency. In C350 calves, the effect sizes (Cliff's delta) for milk DMI, ADG, BW, and feed efficiency were positive and small, but negative in C700 calves. Compared with C350 treatment, C700 treatment resulted in greater final BW with moderate effect size. Positive and moderate effects of feeding colostrum (C700 vs. C0) were observed on postweaning $\mathrm{ADG}$ and final $\mathrm{BW}$. The findings showed that the inclusion of $700 \mathrm{~g}$ of colostrum in $5 \mathrm{~kg}$ of milk may be beneficial to the growth and health of dairy calves. Key words: calf, colostrum, health, weight gain

\section{INTRODUCTION}

Evidence suggests that metabolic programming begins during fetal life and continues well into postnatal life (Patel et al., 2009; Bartol et al., 2013). Research in several species indicates that delivery of milk-borne bioactive factors from mother to offspring in early life plays a pivotal role in the programming of later life events by affecting the cellular signaling mechanisms, immune system, and digestive tract growth and differentiation (Bagnell et al., 2009; Bartol et al., 2013; Bagnell and Bartol, 2019).

Bovine colostrum contains nutrients, several bioactive compounds including immunoglobulins, bioactive peptides (cytokines), lactoferrin, oligosaccharides, hormones, and growth factors (insulin-like growth factor-I, epidermal growth factor, and transforming growth factor), and immune-related microRNA, which play critical roles in the health and development of the neonate (Blättler et al., 2001; Scheuer et al., 2006; McGrath, 2016). Early feeding of colostrum is pivotal because of the progressive decline in the uptake of large molecules (e.g., IgG, IgA, and IgM) during the first days of life due to gut closure (Arthington et al., 2000). The less abundant constituents of the bovine colostrum such as monocyte differentiation antigen CD14, xanthine 
dehydrogenase or oxidase, glycosylation-dependent cell adhesion molecule 1, lactadherin, and clusterin (Zhang et al., 2015) may modulate the immune system (Wheeler et al., 2007). Therefore, increasing the duration of colostrum feeding may enhance calf immunity, health, and growth performance in later life.

Short-term feeding of colostrum stimulates morphological growth and functional maturation of the gastrointestinal tract (Bühler et al., 1998; Blum and Hammon, 2000; Hernández-Castellano et al., 2015), promotes the establishment of beneficial bacteria (Malmuthuge et al., 2015; Malmuthuge and Guan, 2017; Ma et al., 2019), enhances glucose uptake via gut absorptive capacity (Hammon et al., 2013), increases plasma glucagon-like peptide-1 concentrations (Inabu et al., 2019), and reduces calf morbidity and mortality (Conneely et al., 2014; Barrett, 2016; Armengol and Fraile, 2016). Chamorro et al. (2017) suggested that feeding $150 \mathrm{~g}$ of $14 \% \mathrm{IgG}$ powder in milk replacer for $14 \mathrm{~d}$ did not affect the weight gain but reduced disease occurrence and antibiotic therapy in dairy calves during the preweaning period.

There is a paucity of studies evaluating the effect of prolonged colostrum feeding during early life on the growth performance of dairy calves. We hypothesized that extended colostrum feeding affects the growth performance and health status of dairy calves. Therefore, the objective of this study was to evaluate the effect of partial replacement of pasteurized whole milk with pasteurized colostrum $(0,350$, and $700 \mathrm{~g} / \mathrm{d})$ for $2 \mathrm{wk}$ on performance and health indicators in Holstein dairy calves.

\section{MATERIALS AND METHODS}

This study was performed from October 31, 2018, to February 5, 2019, at Baharan Milk and Meat Co., Isfahan, Iran. All of the animal procedures were approved by the Animal Care and Use Committee of Shiraz University (IACUC \# 201922) as set by the Iranian Council of Animal Care.

\section{Climatic Conditions, Calves, Treatments, and Management}

During 16 consecutive days, newborn calves were allotted to individual pens (9 calves daily; 3 calves per treatment per day). Air temperature $\left(\mathbf{T} ;{ }^{\circ} \mathrm{C}\right)$ and relative humidity $(\%)$ in the calf barn were recorded daily (Hobo Pro Series Temp probes, Onset Computer Corporation, Pocasset, MA), and temperature-humidity index was computed according to NRC (2001) as shown in Figure 1A.
A total of 144 Holstein heifer calves (2 d of age; BW $=39.3 \pm 0.82 \mathrm{~kg} ;$ dam parity $=2.5 \pm 0.45$; mean \pm $\mathrm{SE})$ were weighed, housed in a naturally ventilated barn with individual pens $(3.0 \mathrm{~m} \times 1.2 \mathrm{~m} \times 1.8 \mathrm{~m}$; length $\times$ width $\times$ height), and monitored daily for any sign of diseases. Screened wood shavings with a minimum theoretical length cut of $50 \mathrm{~mm}$ were used to minimize dustiness in the housing environment. The bedding was refreshed every $2 \mathrm{~d}$, and manure was removed daily to keep the pens visibly clean and dry. Calves were in a maternity pen during the first day of life and then transferred at random to the pens according to treatment allocations to receive daily: (1) $5 \mathrm{~kg}$ of pooled pasteurized whole milk without colostrum $(\mathbf{C 0} ; \mathrm{n}=$ 48), (2) $0.350 \mathrm{~kg}$ of pooled pasteurized colostrum and $4.650 \mathrm{~kg}$ pasteurized whole milk $(\mathbf{C} 350 ; \mathrm{n}=48)$, and (3) $0.700 \mathrm{~kg}$ of pooled pasteurized colostrum and 4.300 $\mathrm{kg}$ of pasteurized whole milk $(\mathbf{C 7 0 0} ; \mathrm{n}=48)$. These treatments were applied for $14 \mathrm{~d}$, and the calves were fed daily with $5 \mathrm{~kg} / \mathrm{d}$ of pooled pasteurized whole milk (warmed to $39.5 \pm 0.5^{\circ} \mathrm{C}$ using a water bath) until d 56 ; this was followed by a step-down decrease $(1 \mathrm{~kg} / \mathrm{d})$ in offered milk until weaning on d 61 ; there were no refusals of liquid feed. However, data recording continued until d 81.

Pasteurized whole milk $\left(65^{\circ} \mathrm{C}\right.$ for 30 min; Sanaye Boroodati Nasr Inc., Isfahan, Iran) and colostrum $\left(60^{\circ} \mathrm{C}\right.$ for $40 \mathrm{~min}$; Davoodi Livestock Engineering Group, Isfahan, Iran) were mixed at ratios of $\sim 14: 1$ (C350) and $\sim 7: 1$ (C700) as treatment groups. Samples of whole milk, colostrum, and their blends (1 sample at each feeding time) were preserved with potassium dichromate, stored at $4^{\circ} \mathrm{C}$, and sent to the Central Milk Testing Laboratory of the farm for determination of DM, fat, and protein concentrations using an infrared analyzer (MilkoScan 134 BN; Foss Electric, Hillerød, Denmark; Table 1). These values were used to calculate daily nutrient intake.

The quality of pooled colostrum samples was determined daily using a Reichert AR 200 Digital Handheld Refractometer (Reichert Inc., Depew, NY). Daily colostrum (Brix value $=25 \pm 1.24 \%$, range: $22-28 \%$ ) obtained from healthy cows was pooled, pasteurized, and fed to calves at $\sim 6.5 \%$ of birth weight at 1 and $12 \mathrm{~h}$ after birth. From d 2 onward, the calves were allocated to respective treatments and individually received 2.5 $\mathrm{kg}$ of liquid feed in the morning $(0800 \mathrm{~h})$ and $2.5 \mathrm{~kg}$ in the evening $(1800 \mathrm{~h})$. Twenty-four hours after the first feeding of colostrum, jugular blood samples were taken into Vacutainer tubes (BD Vacutainer, Franklin Lakes, NJ) containing spray-coated silica to determine serum total protein using a commercially available hand-held clinical refractometer (model ATA-2771; Atago Co. 
A

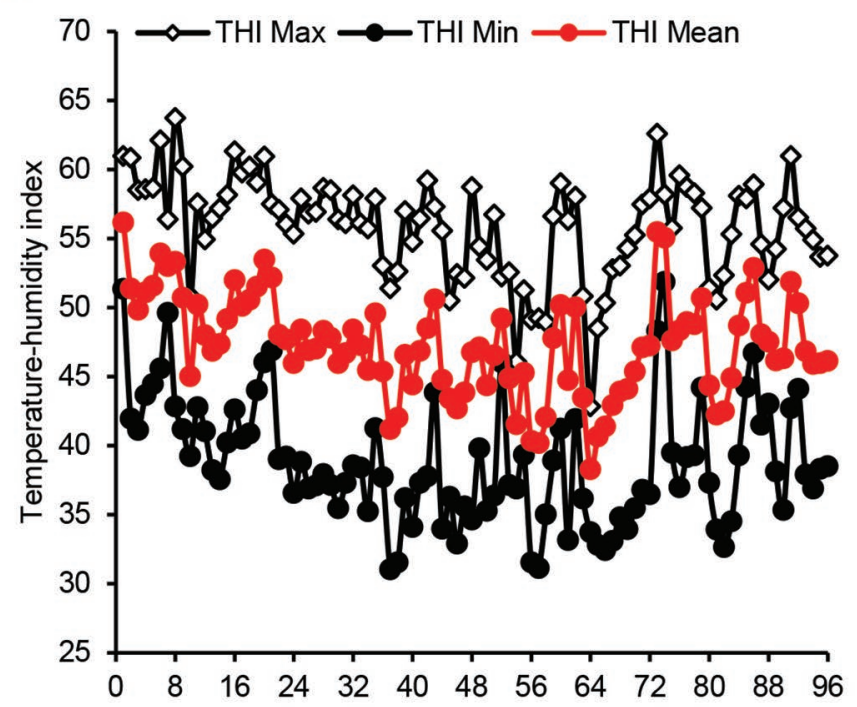

C

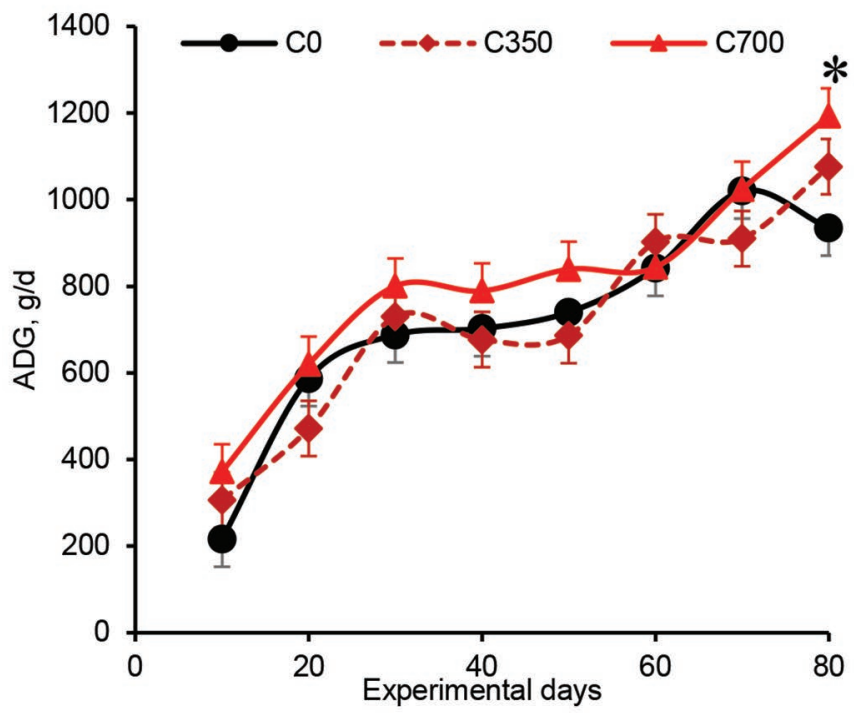

B

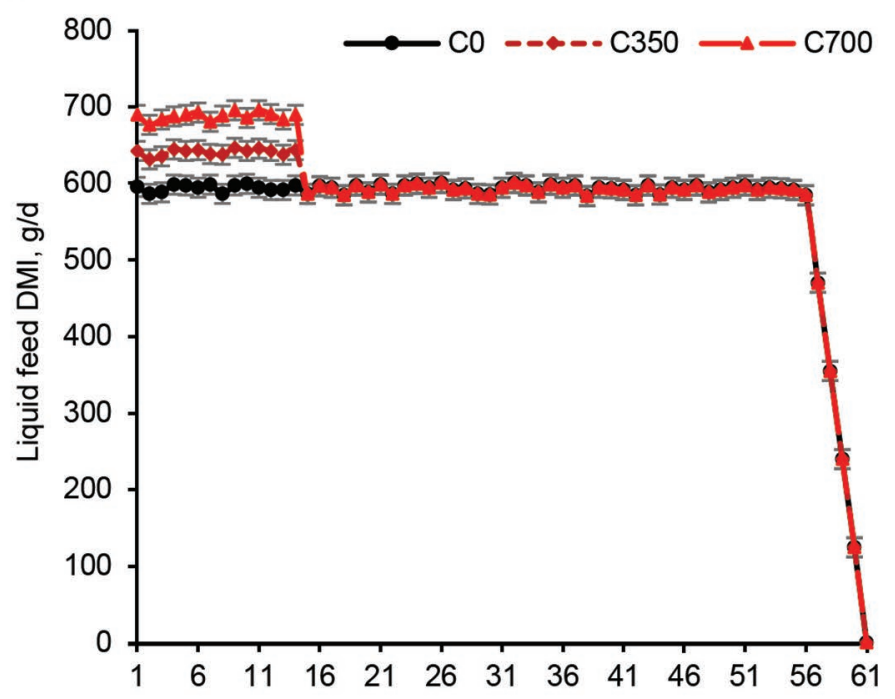

D

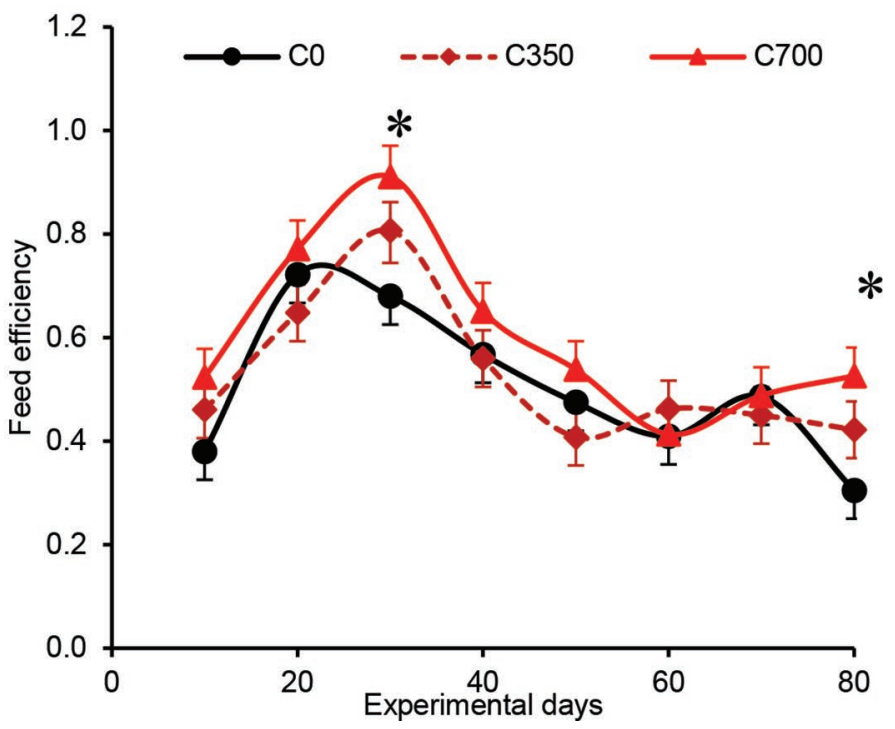

Figure 1. (A) Temporal patterns of maximum (Max), minimum (Min), and average (Mean) temperature-humidity index (THI) during the study period. The average maximum THI, minimum relative humidity, and maximum temperature were $55.8 \pm 3.7,30.6 \pm 12.8 \%$, and $12.6 \pm$ $3.1^{\circ} \mathrm{C}$, respectively. (B) Liquid feed (colostrum + whole milk) DMI (g/d) as influenced by incremental replacement of pasteurized whole milk with pasteurized colostrum in liquid feed for neonatal Holstein dairy calves during the preweaning period. Treatments were $\mathrm{C} 0=$ calves received daily $5 \mathrm{~kg}$ of pooled pasteurized whole milk from d 1 to 14 of the study; C350 = calves received daily mixture of $0.350 \mathrm{~kg}$ of pooled pasteurized colostrum and $4.650 \mathrm{~kg}$ of pooled pasteurized whole milk from d 1 to 14 of the study; and $\mathrm{C} 700=$ calves received daily mixture of $0.700 \mathrm{~kg}$ of pooled pasteurized colostrum and $4.300 \mathrm{~kg}$ of pooled pasteurized whole milk from d 1 to 14 of the study. From d 15 onward, all calves were fed individually with $5 \mathrm{~kg} / \mathrm{d}$ of pasteurized whole milk, weaned on d 61 , and monitored until d 81 of the study. The SEM $=2.60$. Effects in model: treatment (Treat): $P=0.001$; period (PD): $P=0.001$; Treat $\times$ PD: $P=0.001$. (C) Average daily gain $(\mathrm{g} / \mathrm{d})$ as influenced by incremental replacement of pasteurized whole milk with pasteurized colostrum in liquid feed for neonatal Holstein dairy calves during the study period. The SEM $=24.85$. Effects in model were treatment (Treat): $P=0.02$; period $(\mathrm{PD}): P=0.001$; Treat $\times$ PD: $P=0.001$. For each time point, $*$ denotes significant difference at $P \leq 0.05$. (D) Feed efficiency (ADG/total DMI) as influenced by incremental replacement of pasteurized whole milk with pasteurized colostrum in liquid feed for neonatal Holstein dairy calves during the study period. The SEM $=0.02$. Effects in model were treatment (Treat): $P=0.02$; period (PD): $P=0.001$; Treat $\times \mathrm{PD}: P=0.006$. For each time point, ${ }^{*}$ denotes significant difference at $P \leq 0.05$.

Ltd., Tokyo, Japan). The bottom threshold (>5.5 mg/ dL; Tyler et al., 1996) for passive transfer of immunoglobulins was equal in all treatment groups, and only calves with a serum total protein level $>5.5 \mathrm{mg} / \mathrm{dL}$ were included in the study. The average serum total protein concentration was $5.69 \pm 0.16,5.89 \pm 0.15$, 
Table 1. Average daily nutrient composition of colostrum and the experimental liquid feeds $( \pm \mathrm{SD})$

\begin{tabular}{|c|c|c|c|c|}
\hline \multirow[b]{2}{*}{ Chemical composition } & \multirow[b]{2}{*}{ Colostrum } & \multicolumn{3}{|c|}{ Treatment $^{1}$} \\
\hline & & $\mathrm{C} 0$ & C350 & $\mathrm{C} 700$ \\
\hline DM, $\%$ & $25.00 \pm 1.24$ & $11.83 \pm 0.12$ & $12.75 \pm 0.18$ & $13.67 \pm 0.15$ \\
\hline $\mathrm{CP}, \%$ of $\mathrm{DM}$ & $51.24 \pm 1.62$ & $23.63 \pm 0.15$ & $25.56 \pm 0.25$ & $27.50 \pm 0.34$ \\
\hline Fat, $\%$ of $\mathrm{DM}$ & $19.80 \pm 1.38$ & $26.16 \pm 1.04$ & $25.71 \pm 1.12$ & $25.27 \pm 1.20$ \\
\hline $\mathrm{ME},{ }^{2} \mathrm{Mcal} / \mathrm{kg}$ of DM & $5.25 \pm 0.06$ & $5.11 \pm 0.03$ & $5.12 \pm 0.04$ & $5.13 \pm 0.05$ \\
\hline
\end{tabular}

${ }^{1}$ Treatments: $\mathrm{C} 0=$ calves received daily $5 \mathrm{~kg}$ of pooled pasteurized whole milk from $\mathrm{d} 1$ to 14 of the study; $\mathrm{C} 350=$ calves received daily mixture of $0.350 \mathrm{~kg}$ of pooled pasteurized colostrum and $4.650 \mathrm{~kg}$ of pooled pasteurized whole milk from d 1 to 14 of the study; C700 = calves received daily mixture of $0.700 \mathrm{~kg}$ of pooled pasteurized colostrum and $4.300 \mathrm{~kg}$ of pooled pasteurized whole milk from d 1 to 14 of the study. From d 15 onward, all calves were fed individually with $5 \mathrm{~kg} / \mathrm{d}$ of pasteurized whole milk, weaned on $\mathrm{d} 61$, and monitored until d 81 of the study.

${ }^{2}$ Calculated from NRC (2001).

and $5.80 \pm 0.16 \mathrm{mg} / \mathrm{dL}($ mean $\pm \mathrm{SD})$ in $\mathrm{C} 0, \mathrm{C} 350$, and C700, respectively. The calves had free access to water and starter feed (steel buckets) formulated according to the NRC (2001), allowing for at least $10 \%$ refusals. The ingredients and nutrient composition of the starter feed are given in Supplemental Table S1 (https://doi.org/10 $.3168 /$ jds.2020-18355).

\section{Feed Sampling and Analyses}

Feed refusals were removed before the provision of fresh starter feed (at $1000 \mathrm{~h}$ ). Individual feed intake was determined daily by weighing the amounts of starter feed offered and the amounts refused using a calibrated electronic scale (model PX3000; Pand Iran Co., Isfahan, Iran). Representative samples of alfalfa hay and basal starter feed $(\mathrm{n}=9$; pooled by feed type every $10 \mathrm{~d})$ and refusals $(\mathrm{n}=8$; pooled by calf every 10 d) were taken before the morning feeding. The sample $\mathrm{DM}$ concentration was measured by drying at $100^{\circ} \mathrm{C}$ in a forced-air oven for $24 \mathrm{~h}$ (AOAC International, 2002; method 925.40). After mixing, the samples were ground to pass a 1-mm screen (Wiley mill, Ogawa Seiki Co. Ltd., Tokyo, Japan) and analyzed in triplicate for CP (Kjeltec 1030 Auto Analyzer, Tecator, Höganäs, Sweden; AOAC International, 2002; method 955.04), ether extract (EE; AOAC International, 2002; method 920.39), ash (AOAC International, 2002; method 942.05), and NDF using a heat-stable $\alpha$-amylase (100 $\mu \mathrm{L} / 0.5 \mathrm{~g}$ of sample) and sodium sulfite (Van Soest et al., 1991). The NFC component was computed (NRC, 2001) as $100-(\mathrm{CP}+\mathrm{NDF}+\mathrm{EE}+$ ash $)$.

\section{Growth and Skeletal Measurements}

Body weight was measured on the first day of the study and every $10 \mathrm{~d}$ thereafter before the morning feeding using an electronic scale (model EES-500; Ette- had Inc., Isfahan, Iran), which was calibrated by the manufacturer's agent before the initiation of the study and every month thereafter. Average daily gain (g/d) was calculated as the difference between BW taken at $10-d$ intervals divided by 10 . Body weight was also used to compute weight gains during the preweaning $(\mathrm{d}$ 1-60), postweaning (d 61-81), and overall (d 1-81) periods. Feed efficiency $(\mathbf{F E})$ was calculated as the ratio of ADG to DMI (liquid feed DMI + starter feed DMI).

Body size measurements, including the heart girth (chest circumference), withers height (distance from the base of the front feet to withers), body length (distance between the points of shoulder and rump), hip height (distance from the base of the rear feet to hook bones), and hip width (distance between the points of hook bones), were measured manually on the first day, at weaning (d 61), and at the end of study (d 81) as described by Pazoki et al. (2017). The measurements were taken by an individual who satisfied high interobserver reliability [Cohen's kappa coefficient $\left(\kappa_{W}\right)>0.86$ ] for each measurement. The values were used to calculate the skeletal growth during preweaning (d 1-60), postweaning (d 61-81), and overall (d 1-81) periods.

\section{Health Status}

Calves were observed daily for health status based on their appetite to consume milk and starter, as well as their general appearance by a veterinarian blinded to the treatments, according to a referenced standard (Larson et al., 1977) modified by Heinrichs et al. (2003). The general appearance score was assigned as $1=$ normal and alert; $2=$ ears drooped; $3=$ head and ears drooped, dull eyes, slightly lethargic; $4=$ head and ears drooped, dull eyes, lethargic; and $5=$ severely lethargic. The fecal score was determined daily at $0700 \mathrm{~h}$ based on fecal consistency $(1=$ normal; $2=$ soft to loose; 3 $=$ loose to watery; $4=$ watery, mucous, and slightly 
bloody; and $5=$ watery, mucous, and bloody). Rectal temperature (RT) was measured daily between 1200 and $1400 \mathrm{~h}$ using a digital thermometer (model CT20; EmsiG GmbH, Hamburg, Germany) placed in the rectum for approximately $10 \mathrm{~s}$. The general appearance was categorized as the number of days with a general appearance score $\geq 2$, the fecal score was categorized as the number of days with a fecal score $\geq 3$, and RT was categorized as the number of days with $\mathrm{T} \geq 39.4^{\circ} \mathrm{C}$ (as fever threshold). These categories were denoted as days with abnormal general appearance, fecal score, and RT, respectively.

Diagnosis of diarrhea and pneumonia was performed by a veterinarian, and treated following the standard procedures at the Baharan Milk and Meat Co. (Isfahan, Iran). Calves with diarrhea received a water-based oral rehydration salt solution $(1 \mathrm{~L} / \mathrm{d}$ per calf for 2 consecutive days; Rooyan-e-Isfahan Co., Isfahan, Iran) and sulfadimidine syrup (sulfadimidine sodium 33.3\%; 15 $\mathrm{mL} / \mathrm{d}$ per calf for 2 consecutive days; Fan-Avari Zisti Kimia Co., Arak, Iran). Nonresponding individuals were treated for 3 more days with enrofloxacin (10\%; $5 \mathrm{~mL}$ per calf; Tolide Darouhai Dami Co., Tehran, Iran) and Pantrisul [trimethoprim (200 mg/mL) + sulfamethoxazole $(200 \mathrm{mg} / \mathrm{mL}) ; 2.5 \mathrm{~mL}$ per calf; Makian Daru Co., Tehran, Iran]. To treat pneumonia, the calves were administered Dexacoid (dexamethasone; 5 $\mathrm{mL}$ per calf for $1 \mathrm{~d}$; Nasr Pharmaceutical Co., Tehran, Iran), florfenicol (F-Nex 300; $10 \mathrm{~mL}$ per calf on $\mathrm{d} 1$ and 3; Razak Laboratories Co., Karaj, Iran), and oxytetracycline (Oxyvet 10\%; $10 \mathrm{~mL}$ per calf on $\mathrm{d} 1$ and 3; Razak Laboratories Co.). After $1 \mathrm{~d}$, the nonresponding individuals were treated for 2 more days with Pneumosin [tilmicosin $(300 \mathrm{mg} / \mathrm{mL}) ; 10 \mathrm{~mL}$ per calf for 2 consecutive days; Nasr Pharmaceutical Co.].

\section{Statistical Analyses}

A pre-study power analysis for sample size estimation was performed for the primary response variables, including feed intake and ADG, based on previously reported values (Abdelsamei et al., 2005; DeVries and von Keyserlingk, 2009; Kargar and Kanani, 2019; Kargar et al., 2019). From the power test analysis, using $\alpha=0.05$ and power $=0.85$, the projected sample size was approximately a total of 48 calves (16 calves per treatment) for DMI and ADG. A total of 144 calves was enough to get a significant result with adequate probability (power) on growth performance across the treatments according to the power analysis performed by POWER PROC of SAS (version 9.4, SAS Institute Inc., Cary, NC). Repeated-measures data (feed intake and growth performance) were analyzed for preweaning (d 1-60), postweaning (d 61-81), and overall (d 1-81 of the study) periods using PROC MIXED of SAS. The model consisted of birth order of calves, treatment (Treat; C0, C350, or C700), period (PD; 1- or 10-d $\mathrm{PD}$ ), and Treat $\times \mathrm{PD}$ as the fixed effects, and calf within PD and temperature-humidity index as the random effects. The first-order autoregressive covariance structure was the best fit for these data as determined by the lowest Bayesian information criterion. Initial BW, initial skeletal size, and starter DMI were used as covariates in the BW, skeletal measurements, and ADG models, respectively. Data on initial BW, skeletal size, and gains were analyzed using the same model without the PD effect. Data were reported as least squares means, and the Tukey-Kramer adjustment was applied to account for multiple comparisons. The threshold of significance was set at $P \leq 0.05$; trends were declared at $0.05<P \leq 0.10$.

Models for the occurrence of diarrhea $\geq 3$, pneumonia, $\mathrm{RT} \geq 39.4^{\circ} \mathrm{C}$, and general appearance $\geq 2$ were tested by logistic regression using a binomial distribution in the GLIMMIX procedure in SAS. The odds ratio was used to compare the likelihood for calves on each treatment to experience any event. Frequency and duration of diarrhea and pneumonia and the number of days with diarrhea $\geq 3$, pneumonia, $\mathrm{RT} \geq 39.4^{\circ} \mathrm{C}$, and general appearance $\geq 2$ were tested with a Poisson regression model using PROC GENMOD of SAS.

Cliff's delta ( $d$; effect sizes) of 8 parameters were calculated (Cliff, 1993) for comparison of 3 independent groups (C350 vs. C0, C700 vs. C0, and C700 vs. C350) using the scikits bootstrap package (https://github .com/cgevans/scikits-bootstrap). The Cliff's delta estimator was calculated as

$$
d=\frac{\#\left(X_{1}>X_{2}\right)-\#\left(X_{1}<X_{2}\right)}{n_{1} \times n_{2}} .
$$

In this expression, $X_{1}$ and $X_{2}$ were scored within group 1 (e.g., C350 or C700) and group 2 (e.g., C0 or C350), and $n_{1}$ and $n_{2}$ were the sizes of the sample groups. The cardinality symbol \# indicates the number of times a value from the test sample (e.g., C350 or C700) exceeds (or is less than) values in the control sample (e.g., $\mathrm{C} 0$ or C350). This statistic estimates the probability that the value selected from one of the groups is greater than a value selected from the other group, minus the reverse probability. Cliff's delta ranges from -1 to 1 . An effect size of +1 or -1 indicates the absence of overlap between the 2 groups, whereas a 0.0 indicates that group distributions overlap completely. Cliff's delta was, as per standard practice, referred to as negligible $(|d|<$ $0.15)$, small $(|d|<0.33)$, moderate $(|d|<0.47)$, or large $(|d|>0.47)$ (Romano et al., 2006). 


\section{RESULTS}

\section{Intake and Growth Performance}

Replacing part of the whole milk with colostrum increased liquid feed DMI but decreased milk DMI (Figure 1B; Tables 1 and 2). There was no effect of treatment on nutrient intake, but intake of nutrients increased $(P<0.001)$ with advancing age (Table 2$)$.
Calves fed C700 had greater weaning and final BW compared with calves fed $\mathrm{C} 0(P<0.05$; Table 2$)$; the C700 calves also recorded greater BW changes during the postweaning $(+4.2 \mathrm{~kg} ; P=0.01)$ and overall $(+8.1$ kg; $P=0.02$ ) periods. Compared with $\mathrm{C} 0$, the $\mathrm{C} 700$ calves had greater ADG (Figure 1C and Table 2) and improved FE (Figure 1D and Table 2) throughout the study. A Treat $\times$ PD interaction effect $(P=0.001)$ indicated greater $\mathrm{ADG}$ in $\mathrm{C} 700$ versus $\mathrm{C} 0$ calves on $\mathrm{d}$

Table 2. Nutrient intake and growth performance as influenced by incremental replacement of pasteurized whole milk with pasteurized colostrum in liquid feed for neonatal Holstein dairy calves

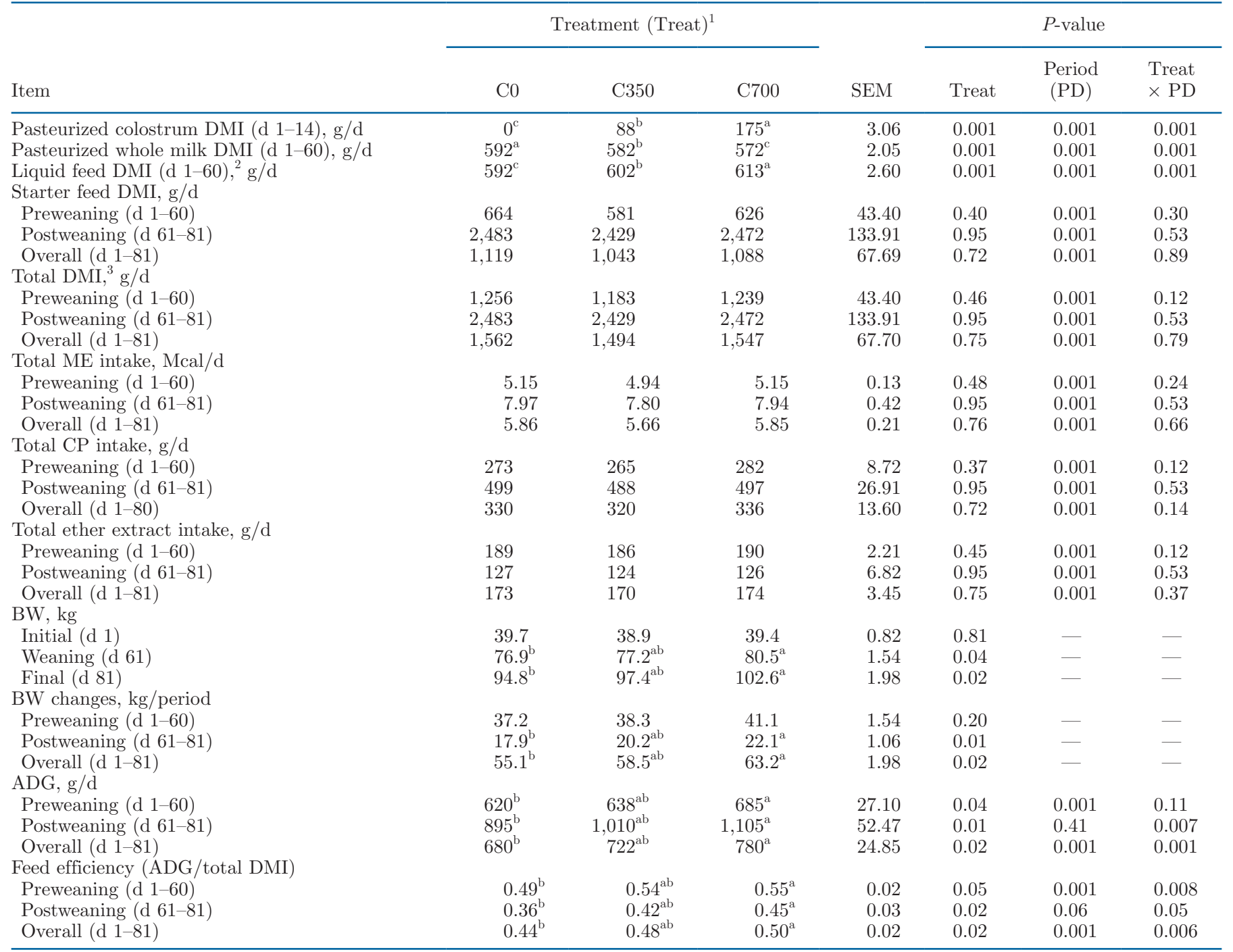

${ }^{\mathrm{a}-\mathrm{c}}$ Means within a row with different superscripts are significantly different $(P \leq 0.05)$.

${ }^{1}$ Treatments: $\mathrm{C} 0=$ calves received daily $5 \mathrm{~kg}$ of pooled pasteurized whole milk from d 1 to 14 of the study; C350= calves received daily mixture of $0.350 \mathrm{~kg}$ of pooled pasteurized colostrum and $4.650 \mathrm{~kg}$ of pooled pasteurized whole milk from d 1 to 14 of the study; C700 = calves received daily mixture of $0.700 \mathrm{~kg}$ of pooled pasteurized colostrum and $4.300 \mathrm{~kg}$ of pooled pasteurized whole milk from d 1 to 14 of the study. From d 15 onward, all calves were fed individually with $5 \mathrm{~kg} / \mathrm{d}$ of pasteurized whole milk, weaned on d 61, and monitored until d 81 of the study.

${ }^{2}$ Liquid feed DMI $(\mathrm{g} / \mathrm{d})=$ pasteurized colostrum DMI + pasteurized whole milk DMI.

${ }^{3}$ Total DMI $(\mathrm{g} / \mathrm{d})=$ liquid feed DMI + starter feed DMI. 
Table 3. Skeletal growth as influenced by incremental replacement of pasteurized whole milk with pasteurized colostrum in liquid feed for neonatal Holstein dairy calves

\begin{tabular}{|c|c|c|c|c|c|}
\hline \multirow[b]{2}{*}{ Item } & \multicolumn{3}{|c|}{ Treatment $(\text { Treat })^{1}$} & \multirow[b]{2}{*}{ SEM } & \multirow{2}{*}{$\frac{P \text {-value }}{\text { Treat }}$} \\
\hline & $\mathrm{C} 0$ & C350 & $\mathrm{C} 700$ & & \\
\hline Initial heart girth $(\mathrm{d} 1), \mathrm{cm}$ & 79.8 & 79.3 & 80.3 & 0.83 & 0.70 \\
\hline \multicolumn{6}{|l|}{ Heart girth changes, $\mathrm{cm} /$ period } \\
\hline Preweaning (d 1-60) & $19.5^{\mathrm{b}}$ & $22.0^{\mathrm{ab}}$ & $24.6^{\mathrm{a}}$ & 1.43 & 0.05 \\
\hline Postweaning (d 61-81) & 9.7 & 8.4 & 10.4 & 1.41 & 0.49 \\
\hline Overall (d 1-81) & $29.2^{\mathrm{b}}$ & $30.4^{\mathrm{ab}}$ & $35.0^{\mathrm{a}}$ & 2.10 & 0.04 \\
\hline Initial withers height $(\mathrm{d} 1), \mathrm{cm}$ & 79.4 & 76.9 & 78.5 & 0.98 & 0.21 \\
\hline \multicolumn{6}{|l|}{ Withers height changes, $\mathrm{cm} /$ period } \\
\hline Preweaning (d 1-60) & 15.2 & 15.1 & 15.2 & 0.67 & 0.93 \\
\hline Postweaning (d 61-81) & 3.9 & 3.5 & 5.4 & 0.96 & 0.20 \\
\hline Overall (d 1-81) & 19.1 & 18.6 & 20.6 & 1.12 & 0.44 \\
\hline Initial body length girth (d 1), cm & 42.7 & 39.9 & 42.2 & 1.02 & 0.14 \\
\hline \multicolumn{6}{|l|}{ Body length changes, $\mathrm{cm} /$ period } \\
\hline Preweaning (d 1-60) & 17.0 & 17.4 & 17.0 & 0.49 & 0.80 \\
\hline Postweaning (d 61-81) & 2.3 & 2.5 & 2.7 & 0.51 & 0.88 \\
\hline Overall (d 1-81) & 19.3 & 19.9 & 19.6 & 0.46 & 0.68 \\
\hline Initial hip height (d 1), $\mathrm{cm}$ & 81.2 & 78.1 & 80.2 & 1.04 & 0.12 \\
\hline \multicolumn{6}{|l|}{ Hip height changes, $\mathrm{cm} /$ period } \\
\hline Preweaning (d 1-60) & 14.9 & 15.4 & 14.4 & 0.66 & 0.52 \\
\hline Postweaning (d 61-81) & 5.5 & 4.9 & 6.4 & 0.57 & 0.19 \\
\hline Overall (d 1-81) & 20.4 & 20.3 & 20.7 & 0.74 & 0.91 \\
\hline Initial hip width (d 1), cm & 12.8 & 12.9 & 12.9 & 0.17 & 0.77 \\
\hline \multicolumn{6}{|l|}{ Hip width changes, $\mathrm{cm} /$ period } \\
\hline Preweaning (d 1-60) & 3.8 & 3.7 & 3.4 & 0.18 & 0.27 \\
\hline Postweaning (d 61-81) & 1.7 & 1.8 & 2.0 & 0.21 & 0.56 \\
\hline Overall (d 1-81) & 5.5 & 5.5 & 5.4 & 0.24 & 0.95 \\
\hline
\end{tabular}

${ }^{\mathrm{a}, \mathrm{b}}$ Means within a row with different superscripts are significantly different $(P \leq 0.05)$.

${ }^{1}$ Treatments: $\mathrm{C} 0=$ calves received daily $5 \mathrm{~kg}$ of pooled pasteurized whole milk from d 1 to 14 of the study; $\mathrm{C} 350=$ calves received daily mixture of $0.350 \mathrm{~kg}$ of pooled pasteurized colostrum and $4.650 \mathrm{~kg}$ of pooled pasteurized whole milk from d 1 to 14 of the study; $\mathrm{C} 700=$ calves received daily mixture of $0.700 \mathrm{~kg}$ of pooled pasteurized colostrum and $4.300 \mathrm{~kg}$ of pooled pasteurized whole milk from d 1 to 14 of the study. From d 15 onward, all calves were fed individually with $5 \mathrm{~kg} / \mathrm{d}$ of pasteurized whole milk, weaned on $\mathrm{d}$ 61, and monitored until d 81 of the study.

80 (Figure $1 \mathrm{C}$ and Table 2). There was also a significant Treat $\times \mathrm{P}$ interaction effect $(P=0.006)$ showing increased $\mathrm{FE}$ in $\mathrm{C} 700$ versus $\mathrm{C} 0$ calves on $\mathrm{d} 30$ and 80 (Figure 1D and Table 2). The C350 calves tended ( $P$ $\leq 10$ ) to have greater ADG and $\mathrm{BW}$ gain (during the postweaning and overall periods) and FE (throughout the study) compared with $\mathrm{C} 0$.

The withers height, body length, hip height, and hip width changes were not affected by the treatments, but C700 calves showed greater heart girth change during the preweaning $(+5.1 \mathrm{~cm} ; P=0.05)$ and overall $(+5.8$ $\mathrm{cm} ; P=0.04)$ periods compared with the $\mathrm{C} 0$ calves (Table 3).

\section{Health Criteria}

Table 4 presents the logistic models for the occurrence of elevated $\mathrm{RT}\left(\geq 39.4^{\circ} \mathrm{C}\right)$, general appearance score $\geq 2$, diarrhea (score $\geq 3$ ), and pneumonia before weaning ( $\mathrm{d}$ 1-60). The occurrence of elevated RT was higher in calves fed milk compared with colostrum-supplemented calves $[(\mathrm{C} 350$ odds ratio $=6.70 ; P=0.001)$ or $(\mathrm{C} 700$ odds ratio $=5.90 ; P=0.001)]$. Calves fed $\mathrm{C} 0$ had a higher chance of having general appearance score $\geq 2$ compared with calves fed C350 (odds ratio $=19.64 ; P$ $=0.001)$ or $\mathrm{C} 700$ (odds ratio $=14.71 ; P=0.001$ ). The occurrence of diarrhea was lower in calves fed C700 compared with calves fed $\mathrm{C} 0$ (odds ratio $=1.67 ; P$ $=0.04$ ) and $\mathrm{C} 350$ (odds ratio $=1.71 ; P=0.03$ ). The occurrence of pneumonia tended to increase in calves fed milk compared with colostrum-supplemented calves $(\mathrm{C} 350$ odds ratio $=1.88 ; P=0.06$ or $\mathrm{C} 700$ odds ratio $=1.88 ; P=0.06)$.

Days with elevated RT $\left(\geq 39.4^{\circ} \mathrm{C}\right)$ and general appearance score $(\geq 2)$ were greater in $\mathrm{C} 0$ than in C350 and C700 calves (Table 5; $P<0.01$ ). Duration of diarrhea was lower $(P=0.03)$ in calves in the $\mathrm{C} 700$ treatment compared with $\mathrm{C} 0$ or C350 calves. Calves fed milk containing colostrum experienced fewer days with pneumonia $(P=0.05)$. 
Table 4. Logistic model for rectal temperature $\geq 39.4^{\circ} \mathrm{C}$, general appearance ${ }^{1} \geq 2$, diarrhea ${ }^{2} \geq 3$, or pneumonia occurrence during the preweaning period (d 1-60) as influenced by incremental replacement of pasteurized whole milk with pasteurized colostrum in liquid feed for neonatal Holstein dairy calves

\begin{tabular}{|c|c|c|c|c|c|}
\hline Variable and comparison ${ }^{3}$ & Coefficient & SEM & $\mathrm{OR}^{4}$ & $95 \% \mathrm{CI}$ & $P$-value \\
\hline \multicolumn{6}{|l|}{ Rectal temperature } \\
\hline C0 vs. C350 & 1.9028 & 0.23 & 6.70 & $4.25,10.57$ & 0.001 \\
\hline C0 vs. C700 & 1.7762 & 0.22 & 5.90 & $3.82,9.11$ & 0.001 \\
\hline C350 vs. C700 & -0.1266 & 0.29 & 0.88 & $0.49,1.55$ & 0.66 \\
\hline \multicolumn{6}{|l|}{ General appearance } \\
\hline C0 vs. C350 & 2.9780 & 0.59 & 19.64 & $6.11,63.12$ & 0.001 \\
\hline C0 vs. C700 & 2.6890 & 0.52 & 14.71 & $5.30,40.83$ & 0.001 \\
\hline C350 vs. C700 & -0.2890 & 0.76 & 0.74 & $0.16,3.36$ & 0.70 \\
\hline \multicolumn{6}{|l|}{ Diarrhea occurrence } \\
\hline C0 vs. C350 & -0.0254 & 0.22 & 0.97 & $0.62,1.51$ & 0.91 \\
\hline $\mathrm{C} 0$ vs. $\mathrm{C} 700$ & 0.5161 & 0.25 & 1.67 & $1.00,2.78$ & 0.04 \\
\hline C350 vs. C700 & 0.5416 & 0.25 & 1.71 & $1.03,2.85$ & 0.03 \\
\hline \multicolumn{6}{|l|}{ Pneumonia occurrence } \\
\hline C0 vs. C350 & 0.6348 & 0.33 & 1.88 & $0.97,3.64$ & 0.06 \\
\hline C0 vs. C700 & 0.6348 & 0.33 & 1.88 & $0.97,3.64$ & 0.06 \\
\hline C350 vs. C700 & 0.0000 & 0.38 & 1.00 & $0.47,2.11$ & 1.00 \\
\hline
\end{tabular}

${ }^{1} 1=$ normal and alert; $2=$ ears drooped; $3=$ head and ears drooped, dull eyes, slightly lethargic; $4=$ head and ears drooped, dull eyes, lethargic; $5=$ severely lethargic (Heinrichs et al., 2003).

${ }^{2} 1=$ normal; $2=$ soft to loose; $3=$ loose to watery; $4=$ watery, mucous, and slightly bloody; $5=$ watery, mucous, and bloody (Heinrichs et al., 2003).

${ }^{3}$ Treatments: $\mathrm{C} 0=$ calves received daily $5 \mathrm{~kg}$ of pooled pasteurized whole milk from d 1 to 14 of the study; $\mathrm{C} 350=$ calves received daily mixture of $0.350 \mathrm{~kg}$ of pooled pasteurized colostrum and $4.650 \mathrm{~kg}$ of pooled pasteurized whole milk from d 1 to 14 of the study; $\mathrm{C} 700=$ calves received daily mixture of $0.700 \mathrm{~kg}$ of pooled pasteurized colostrum and $4.300 \mathrm{~kg}$ of pooled pasteurized whole milk from d 1 to 14 of the study. From d 15 onward, all calves were fed individually with $5 \mathrm{~kg} / \mathrm{d}$ of pasteurized whole milk, weaned on $\mathrm{d}$ 61, and monitored until d 81 of the study.

${ }^{4}$ The odds ratio $(\mathrm{OR})$ indicates the probability of either having elevated rectal temperature $\left(\geq 39.4^{\circ} \mathrm{C}\right)$, general appearance $\geq 2$, diarrhea $\geq 3$, or pneumonia for the experimental diets (C0 vs. C350; C0 vs. C700; C350 vs. C700). If the $\mathrm{OR}>1$, a given diet in the comparison is more likely to have elevated rectal temperature $\left(\geq 39.4^{\circ} \mathrm{C}\right)$, general appearance $\geq 2$, diarrhea $\geq 3$, or pneumonia than the other diet by a factor of the difference above 1 . If the $\mathrm{OR}<1$, a given diet has a lower probability of occurrence than the other diet.

Table 5. Poisson regression for days with rectal temperature $\geq 39.4^{\circ} \mathrm{C}$ and general appearance ${ }^{1} \geq 2$, and frequency and duration of diarrhea ${ }^{2} \geq 3$ or pneumonia during the preweaning period (d 1-60) as influenced by incremental replacement of pasteurized whole milk with pasteurized colostrum in liquid feed for neonatal Holstein dairy calves

\begin{tabular}{|c|c|c|c|c|c|}
\hline \multirow[b]{2}{*}{ Item } & \multicolumn{3}{|c|}{ Treatment $(\text { Treat })^{3}$} & \multirow[b]{2}{*}{ SEM } & \multirow{2}{*}{$\frac{P \text {-value }}{\text { Treat }}$} \\
\hline & $\mathrm{C} 0$ & C350 & $\mathrm{C} 700$ & & \\
\hline Days with rectal temperature $\geq 39.4^{\circ} \mathrm{C}$ & $10.2^{\mathrm{a}}$ & $1.8^{\mathrm{b}}$ & $2.0^{\mathrm{b}}$ & 0.16 & 0.001 \\
\hline Days with general appearance $\geq 2$ & $4.2^{\mathrm{a}}$ & $0.2^{\mathrm{b}}$ & $0.3^{\mathrm{b}}$ & $\begin{array}{l}0.10 \\
0.40\end{array}$ & 0.001 \\
\hline \multicolumn{6}{|l|}{ Diarrhea } \\
\hline Frequency, times diagnosed & 1.4 & 1.1 & 1.0 & 0.26 & 0.62 \\
\hline Duration, $\mathrm{d}$ & $3.1^{\mathrm{b}}$ & $3.2^{\mathrm{b}}$ & $1.9^{\mathrm{a}}$ & 0.17 & 0.03 \\
\hline \multicolumn{6}{|l|}{ Pneumonia } \\
\hline Frequency, times diagnosed & 0.9 & 0.5 & 0.4 & 0.36 & 0.42 \\
\hline Duration, $\mathrm{d}$ & $2.0^{\mathrm{b}}$ & $1.1^{\mathrm{a}}$ & $1.0^{\mathrm{a}}$ & 0.24 & 0.05 \\
\hline
\end{tabular}

${ }^{a, b}$ Means within a row with different superscripts are significantly different $(P \leq 0.05)$.

${ }^{1} 1=$ normal and alert; $2=$ ears drooped; $3=$ head and ears drooped, dull eyes, slightly lethargic; $4=$ head and ears drooped, dull eyes, lethargic; 5 = severely lethargic (Heinrichs et al., 2003).

${ }^{2} 1=$ normal; $2=$ soft to loose; $3=$ loose to watery; $4=$ watery, mucous, and slightly bloody; $5=$ watery, mucous, and bloody (Heinrichs et al., 2003).

${ }^{3}$ Treatments: $\mathrm{C} 0=$ calves received daily $5 \mathrm{~kg}$ of pooled pasteurized whole milk from d 1 to 14 of the study; C350 = calves received daily mixture of $0.350 \mathrm{~kg}$ of pooled pasteurized colostrum and $4.650 \mathrm{~kg}$ of pooled pasteurized whole milk from d 1 to 14 of the study; $\mathrm{C} 700=$ calves received daily mixture of $0.700 \mathrm{~kg}$ of pooled pasteurized colostrum and $4.300 \mathrm{~kg}$ of pooled pasteurized whole milk from d 1 to 14 of the study. From d 15 onward, all calves were fed individually with $5 \mathrm{~kg} / \mathrm{d}$ of pasteurized whole milk, weaned on $\mathrm{d} 61$, and monitored until d 81 of the study. 


\section{Effect Size}

We computed Cliff's delta (effect sizes) of the extended colostrum feeding (C350 vs. C0, Figure 2A; C700 vs. C0, Figure 2B; C700 vs. C350, Figure 2C) on starter DMI, ADG, BW, and FE. The effect sizes on starter DMI (but not overall DMI), ADG, BW, and $\mathrm{FE}$ for C350 versus $\mathrm{C} 0$ comparison were negligible to small. A positive, small effect of feeding colostrum was observed on postweaning ADG (C350 vs. C0). The effect sizes for C700 versus C350 and C700 versus C0 comparisons were positive. Positive, but negligible to small, effects of colostrum feeding were observed on starter DMI, preweaning and overall ADG, and FE. Also, positive and moderate effects of feeding colostrum (C700 vs. C0) were observed on postweaning ADG and final BW. Inclusion of colostrum in whole milk resulted in improved final BW with moderate effects, and with negligible to small effect sizes on starter DMI, ADG, and FE between 2 colostrum levels.

\section{DISCUSSION}

Most of the research on feeding colostrum to calves has largely focused on the short-term effects (a couple of days; Bühler et al., 1998; Lora et al., 2018; Sadri et al., 2020). The extended feeding of colostrum or transition milk to calves for several days may be commonplace on many dairy farms; however, the benefits of this practice on the growth performance of dairy calves during the pre- and postweaning stages remain unclear. The knowledge derived from the current study could increase the confidence of dairy farmers to extend feeding colostrum to dairy calves, thereby improving calf performance and well-being.

Calves fed milk containing colostrum had higher DMI from the liquid feed than calves that received milk only. Despite the fact that colostrum DMI and total liquid feed DMI were substantially higher when milk was partially replaced with colostrum, the total DMI was comparable among the treatment groups. Our findings showed that the partial replacement of milk with colostrum at $700 \mathrm{~g} / \mathrm{d}$ for an extended period of $2 \mathrm{wk}$ had a carryover effect on the postweaning ADG, resulting in improved final BW. Cliff's delta (a nonparametric effect size) is a robust and informative measure of effect size. Effect sizes are useful when effects expressed in different units need to be combined or compared. Beyond $P$-value interpretations, Cliff's delta was measured in this study to quantify the amount of difference between the 3 groups (C350 vs. C0, C700 vs. C0, and $\mathrm{C} 700$ vs. C350). In the current study, Cliff's delta confirmed that the partial replacement of milk with colostrum at 700 $\mathrm{g} / \mathrm{d}$ for an extended period of $2 \mathrm{wk}$ improved the weight gain of dairy calves during both pre- and postweaning periods. Also, partially replacing milk with colostrum at $350 \mathrm{~g} / \mathrm{d}$ tended to increase the postweaning ADG; however, the size of this effect was small. The amount of bioactive compounds supplied by a higher level of colostrum may explain why C700 calves achieved greater weight gain after the colostrum supplementation. Interestingly, replacing milk with colostrum at $700 \mathrm{~g} / \mathrm{d}$ compared with $350 \mathrm{~g} / \mathrm{d}$ resulted in greater final BW with a moderate effect size and substantiated the higher level of colostrum feeding on performance. In support of this observation, Yang et al. (2015) reported that calves that consumed colostrum gained more BW at d 8 of life in comparison with transition or bulk tank milk. Extended feeding of colostrum powder $(70 \mathrm{~g}$ twice daily) to beef calves during the first 2 wk of life improved ADG at d 28 of age compared with calves fed milk replacer only (Berge et al., 2009). Chamorro et al. (2017) reported that feeding milk replacer enriched with $150 \mathrm{~g}$ of colostrum powder during the first 2 wk of life did not affect BW or ADG, but reduced the occurrence of abnormal feces, abnormal respiration, and antibiotic treatment before weaning period. In the current study, the greater ADG in colostrum-supplemented calves (especially at $700 \mathrm{~g} / \mathrm{d}$ ) may likely be due to the combined effects of greater FE and lower duration of diarrhea and pneumonia.

It is known that postnatal intestinal development in neonatal calves depends on the supply of nutrients, growth factors, and hormones and can be influenced by colostrum intake (Blum, 2006). Some of the bioactive factors in colostrum, including insulin and insulin-like growth factor-1, may have stimulatory effects via their receptors on the intestinal development and function in the neonate (Hammon and Blum, 1997; Blum, 2006). Jones et al. (2004) reported higher FE and a tendency to gain more BW in calves receiving IgG via maternal colostrum compared with calves that received the same amount via colostrum substitute during the first week of life. In the current study, colostrum-supplemented calves (especially at $700 \mathrm{~g} / \mathrm{d}$ ) utilized the nutrients more efficiently; however, the small effect size suggested that the improved ADG may be minimally related to the FE, and that other factors may have mediated the improvement in ADG. Blättler et al. (2001) showed that extended colostrum intake for the first $3 \mathrm{~d}$ of life increased the intestinal surface area (villi length and villi width). Bühler et al. (1998) demonstrated that calves fed colostrum 2 times per day for $3 \mathrm{~d}$ increased the intestinal crypt depth and villous length compared 
A

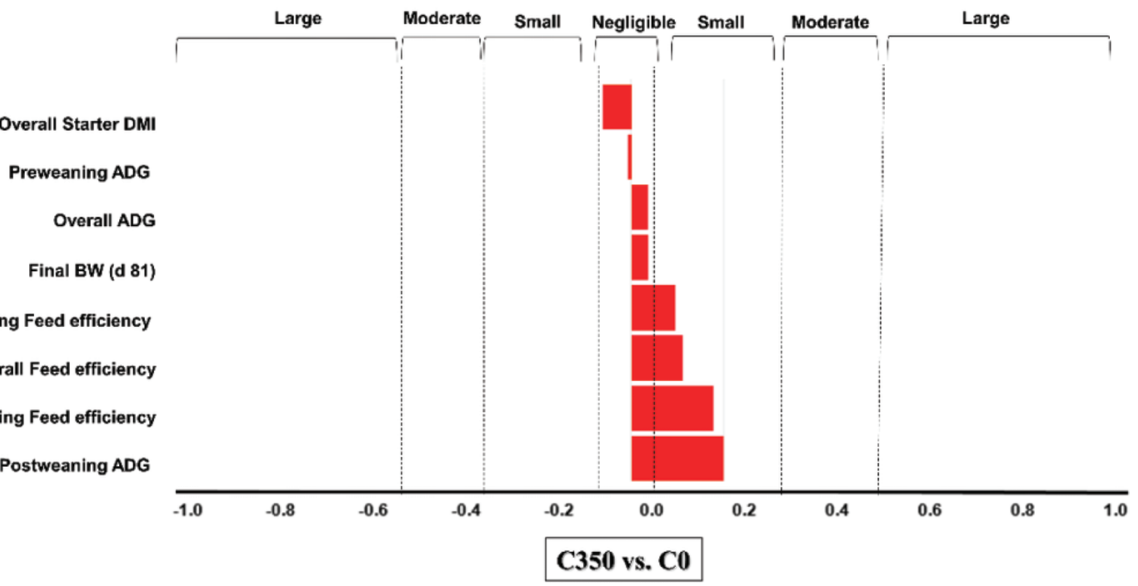

B

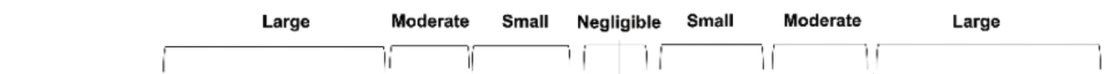

Overall starter DMI

Preweaning ADG

Overall ADG

Preweaning feed efficiency

Overall feed efficiency

Postweaning feed efficiency

Postweaning ADG

Final BW (d 81)
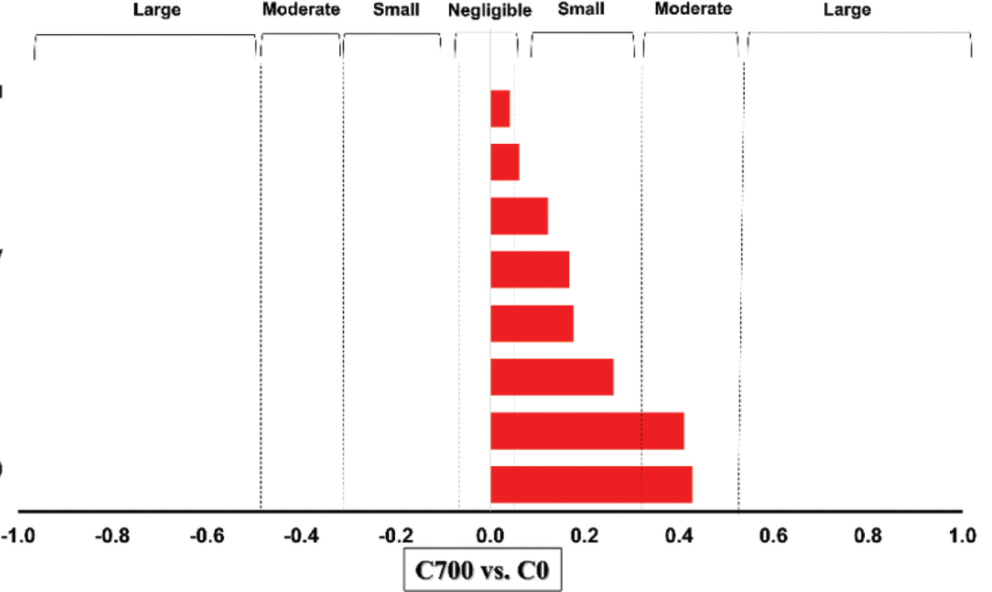

C

Overall Feed efficiency

Preweaning Feed efficiency

Postweaning Feed efficiency

Overall ADG

Preweaning ADG

Postweaning Starter DMI

Postweaning ADG

Final BW

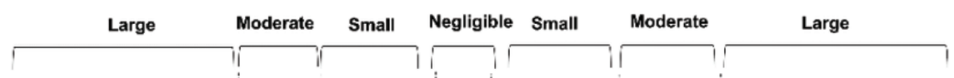

$$
\text { F }
$$
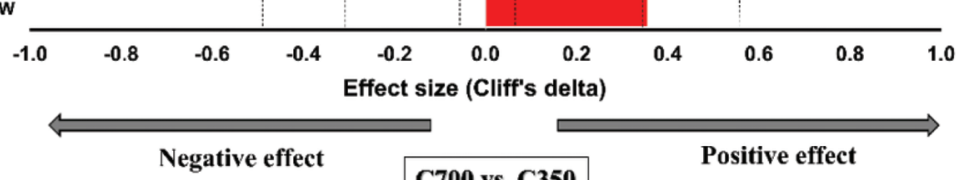

Effect size (Cliff's delta)

Negative effect

C700 vs. C350

Positive effect

Figure 2. The Cliff's delta $(d)$ indices of effect sizes (filled bars) of 2 independent groups (A: C350 vs. C0; B: C700 vs. C0; C: C700 vs. C350) for 8 parameters. Cliff's delta ranges from -1 to 1 and an effect size of +1 or -1 indicates the absence of overlap between the 2 groups, whereas a 0.0 indicates that group distributions overlap completely. Cliff's delta was as per standard practice referred to delta as negligible $(|\mathrm{d}|<0.15)$, small $(|d|<0.33)$, moderate $(|d|<0.47)$, or large $(|d|>0.47)$. Treatments were $\mathrm{C} 0=$ calves received daily $5 \mathrm{~kg}$ of pooled pasteurized whole milk from d 1 to 14 of the study; C350 = calves received daily mixture of $0.350 \mathrm{~kg}$ of pooled pasteurized colostrum and $4.650 \mathrm{~kg}$ of pooled pasteurized whole milk from d 1 to 14 of the study; and $\mathrm{C} 700=$ calves received daily mixture of $0.700 \mathrm{~kg}$ of pooled pasteurized colostrum and $4.300 \mathrm{~kg}$ of pooled pasteurized whole milk from d 1 to 14 of the study. From d 15 onward, all calves were fed individually with $5 \mathrm{~kg} / \mathrm{d}$ of pasteurized whole milk, weaned on $\mathrm{d} 61$, and monitored until d 81 of the study. 
with the calves fed milk replacer. Improved intestinal development may be associated with improved capacity for the absorption of nutrients and better growth performance in colostrum-fed calves (Yang et al., 2015). Overall, the improvement of FE in replacement heifers is beneficial to the dairy industry, as feed is a major cost in raising dairy replacements.

No direct measurements of gastrointestinal tract development and function were performed in the current study, but daily monitoring of fecal scores and medications allowed for a good determination of the health status of each calf individually. In this study, the odds ratios of having abnormal feces and abnormal respiration (tendency) during the preweaning period were higher for calves receiving only milk. Perhaps the localized protective effects of colostral antibodies or other bioactive compounds (Godden, 2008) that remained in the lumen improved the gut immune system or protected calves against the colonization of pathogens. A recent study reported a tendency toward reduced risk of diarrhea in dairy calves supplemented with $3 \mathrm{~g}$ of lactoferrin, an iron-binding protein also found in colostrum, for $3 \mathrm{~d}$ (Pempek et al., 2019). We found a significant decrease in the duration of pneumonia in calves receiving colostrum in their daily milk. In line with our findings, Conneely et al. (2014) reported that providing calves with further feedings of transition milk (for 2 or 4 subsequent feedings), following the initial feeding of colostrum, reduced the likelihood of being assigned a worse eye, ear, and nasal score. In another study, calves receiving $70 \mathrm{~g}$ of colostrum powder in the milk replacer for 14 $\mathrm{d}$ had less diarrhea and received fewer antimicrobial treatments than control calves (Berge et al., 2009). Results from another study suggested that although continuous administration of whole milk with immune colostrum from cows vaccinated with rotavirus to calves after $24 \mathrm{~h}$ of life did not result in further absorption of $\operatorname{IgG}$, the presence of immunoglobulins and other bioactive molecules in colostrum prevented the infections caused by enteric viruses and bacteria (Snodgrass et al., 1982). Finally, our results indicated that partial replacement of milk with colostrum for an extended period of 2 wk could help the calves improve their health status in early life. However, an occasional shortage in high quality colostrum supply is inevitable at the dairy farm. Similar to colostrum, transition milk contains an abundance of bioactive compounds (Blum and Hammon, 2000; McGrath et al., 2016; Fischer et al., 2018). As such, transition milk may be an alternative to colostrum for dairy calves when extra colostrum is unavailable.

\section{CONCLUSIONS}

Our findings showed that the partial replacement of milk with colostrum during the first $14 \mathrm{~d}$ of life had the potential to cause greater weight gain in dairy calves that are fed only with whole milk; this was likely due to better FE and fewer days with diarrhea or pneumonia. The effect size demonstrated that feeding $700 \mathrm{~g} / \mathrm{d}$ of colostrum improved FE, but the size of the effect as measured by Cliff's delta was small. Calves receiving colostrum performed similarly in terms of intakes of starter feed and total DM compared with calves receiving milk after the first colostrum intake. Further studies are needed to identify the molecular mechanisms involved in beneficial effects of such colostrum feeding protocols on calf growth and health.

\section{ACKNOWLEDGMENTS}

The authors are grateful to the Baharan Milk and Meat Co. (Isfahan, Iran) and Shiraz University (Shiraz, Iran) for financial support of this trial. The authors also express their kind appreciation to the farm staffs (Nemat Bakhsh, Ali Reza Nikneshan, Mohammad Moosavian, Jafar Salari, Hadi Dashti, and Moosa Arab) and to Mehdi Mirzaei (Arak University, Arak, Iran) for their help in conducting this research and diligent animal care. The authors express their appreciation to Malek Bahadori-Moghaddam from Shiraz University for completing course requirements for his input to the research and laboratory analyses. We also thank Mohammad Javad Zamiri (Shiraz University) for editing the final English version of this manuscript. The authors declare no conflict of interest.

\section{REFERENCES}

Abdelsamei, A. H., D. G. Fox, L. O. Tedeschi, M. L. Thonney, D. J. Ketchen, and J. R. Stouffer. 2005. The effect of milk intake on forage intake and growth of nursing calves. J. Anim. Sci. 83:940-947. https://doi.org/10.2527/2005.834940x.

AOAC International. 2002. Official Methods of Analysis. 17th ed. AOAC International, Arlington, VA.

Armengol, R., and L. Fraile. 2016. Colostrum and milk pasteurization improve health status and decrease mortality in neonatal calves receiving appropriate colostrum ingestion. J. Dairy Sci. 99:4718 4725. https://doi.org/10.3168/jds.2015-10728.

Arthington, J. D., M. B. Cattell, J. D. Quigley III, G. C. McCoy, and W. L. Hurley. 2000. Passive immunoglobulin transfer in newborn calves fed colostrum or spray-dried serum protein alone or as a supplement to colostrum of varying quality. J. Dairy Sci. 83:28342838. https://doi.org/10.3168/jds.S0022-0302(00)75183-6.

Bagnell, C. A., and F. F. Bartol. 2019. Relaxin and the 'Milky Way': The lactocrine hypothesis and maternal programming of development. Mol. Cell. Endocrinol. 487:18-23. https://doi.org/10.1016/ j.mce.2019.01.003.

Bagnell, C. A., B. G. Steinetz, and F. F. Bartol. 2009. Milk-borne relaxin and the lactocrine hypothesis for maternal programming of 
neonatal tissues. Ann. N. Y. Acad. Sci. 1160:152-157. https://doi .org/10.1111/j.1749-6632.2009.03834.x.

Barrett, D. 2016. Colostrum in neonatal calves: The key to survival, health and performance. Vet. Rec. 179:45-46. https://doi.org/10 $.1136 / v r . i 3607$.

Bartol, F. F., A. A. Wiley, D. J. Miller, A. J. Silva, K. E. Roberts, M. L. P. Davolt, J. C. Chen, A. L. Frankshun, M. E. Camp, K. M. Rahman, J. L. Vallet, and C. A. Bagnell. 2013. Lactation biology symposium: Lactocrine signaling and developmental programming. J. Anim. Sci. 91:696-705. https://doi.org/10.2527/jas.2012-5764.

Berge, A. C. B., T. E. Besser, D. A. Moore, and W. M. Sischo. 2009. Evaluation of the effects of oral colostrum supplementation during the first fourteen days on the health and performance of preweaned calves. J. Dairy Sci. 92:286-295. https://doi.org/10.3168/ jds.2008-1433.

Blättler, U., H. M. Hammon, C. Morel, C. Philipona, A. Rauprich, V. Rome, I. Le Huerou-Luron, P. Guilloteau, and J. W. Blum. 2001. Feeding colostrum, its composition and feeding duration variably modify proliferation and morphology of the intestine and digestive enzyme activities of neonatal calves. J. Nutr. 131:1256-1263. https://doi.org/10.1093/jn/131.4.1256

Blum, J. W. 2006. Nutritional physiology of neonatal calves. J. Anim. Physiol. Anim. Nutr. (Berl.) 90:1-11. https://doi.org/10.1111/j .1439-0396.2005.00614.x.

Blum, J. W., and H. M. Hammon. 2000. Bovine colostrum: More than just an immunoglobulin supplier. Schweiz. Schweiz. Arch. Tierheilkd. 142:221-228.

Bühler, C., H. Hammon, G. L. Rossi, and J. W. Blum. 1998. Small intestinal morphology in eight-day-old calves fed colostrum for different duration or only milk replacer and treated with long-R3insulin-like growth factor I and growth hormone. J. Anim. Sci. 76:758-765. https://doi.org/10.2527/1998.763758x.

Chamorro, M. F., N. Cernicchiaro, and D. M. Haines. 2017. Evaluation of the effects of colostrum replacer supplementation of the milk replacer ration on the occurrence of disease, antibiotic therapy, and performance of preweaned dairy calves. J. Dairy Sci. 100:1378-1387. https://doi.org/10.3168/jds.2016-11652.

Cliff, N. 1993. Dominance statistics: Ordinal analyses to answer ordinal questions. Psychol. Bull. 114:494-509. https://doi.org/10 .1037/0033-2909.114.3.494

Conneely, M., D. R. Berry, J. P. Murphy, I. Lorenz, M. L. Doherty, and E. Kennedy. 2014. Effect of feeding colostrum at different volumes and subsequent number of transition milk feeds on the serum immunoglobulin $\mathrm{G}$ concentration and health status of dairy calves. J. Dairy Sci. 97:6991-7000. https://doi.org/10.3168/jds.2013-7494.

DeVries, T. J., and M. A. G. von Keyserlingk. 2009. Feeding method affects the feeding behavior of growing dairy heifers. J. Dairy Sci. 92:1161-1168. https://doi.org/10.3168/jds.2008-1314.

Fischer, A. J., N. Malmuthuge, L. L. Guan, and M. A. Steele. 2018. Short communication: The effect of heat treatment of bovine colostrum on the concentration of oligosaccharides in colostrum and in the intestine of neonatal male Holstein calves. J. Dairy Sci. 101:401-407. https://doi.org/10.3168/jds.2017-13533.

Godden, S. 2008. Colostrum management for dairy calves. Vet. Clin. North Am. Food Anim. Pract. 24:19-39. https://doi.org/10.1016/ j.cvfa.2007.10.005.

Hammon, H. M., and J. W. Blum. 1997. Prolonged colostrum feeding enhances xylose absorption in neonatal calves. J. Anim. Sci. 75:2915-2919. https://doi.org/10.2527/1997.75112915x.

Hammon, H. M., J. Steinhoff-Wagner, J. Flor, U. Schönhusen, and C. C. Metges. 2013. Lactation Biology Symposium: Role of colostrum and colostrum components on glucose metabolism in neonatal calves. J. Anim. Sci. 91:685-695. https://doi.org/10.2527/jas $.2012-5758$

Heinrichs, A. J., C. M. Jones, L. R. VanRoekel, and M. A. Fowler. 2003. Calf Track: A system of dairy calf workforce management, training, and evaluation and health evaluation. J. Dairy Sci. 86(Suppl. 1):115 (Abstr.).

Hernández-Castellano, L. E., A. Suarez-Trujillo, D. Martell-Jaizme, G. Cugno, A. Arguello, and N. Castro. 2015. The effect of colos- trum period management on BW and immune system in lambs: From birth to weaning. Animal 9:1672-1679. https://doi.org/10 $.1017 /$ S175173111500110X.

Inabu, Y., J. Pyo, S. Pletts, L. L. Guan, M. A. Steele, and T. Sugino. 2019. Effect of extended colostrum feeding on plasma glucagon-like peptide-1 concentration in newborn calves. J. Dairy Sci. 102:46194627. https://doi.org/10.3168/jds.2018-15616.

Jones, C. M., R. E. James, J. D. Quigley III, and M. L. McGilliard. 2004. Influence of pooled colostrum or colostrum replacement on IgG and evaluation of animal plasma in milk replacer. J. Dairy Sci. 87:1806-1814. https://doi.org/10.3168/jds.S0022-0302(04)73337 $-8$.

Kargar, S., and M. Kanani. 2019. Substituting corn silage with reconstituted forage or nonforage fiber sources in the starter feed diets of Holstein calves: Effects on intake, meal pattern, sorting, and health. J. Dairy Sci. 102:7168-7178.

Kargar, S., M. Kanani, M. Albenzio, and M. Caroprese. 2019. Substituting corn silage with reconstituted forage or non-forage fiber sources in the starter diets of Holstein calves: Effects on performance, ruminal fermentation, and blood metabolites. J. Anim. Sci. 97:3046-3055

Larson, L. L., F. G. Owen, J. L. Albright, R. D. Appleman, R. C. Lamb, and L. D. Muller. 1977. Guidelines toward more uniformity in measuring and reporting calf experimental data. J. Dairy Sci. 60:989-991. https://doi.org/10.3168/jds.S0022-0302(77)83975-1.

Lora, I., A. Barberio, B. Contiero, P. Paparella, L. Bonfanti, M. Brscic, A. L. Stefani, and F. Gottardo. 2018. Factors associated with passive immunity transfer in dairy calves: combined effect of delivery time, amount and quality of the first colostrum meal. Animal 12:1041-1049. https://doi.org/10.1017/S1751731117002579.

Ma, T., E. O'Hara, Y. Song, A. Fischer, Z. He, M. A. Steele, and L. L. Guan. 2019. Altered mucosa-associated microbiota in the ileum and colon of neonatal calves in response to delayed first colostrum feeding. J. Dairy Sci. 102:7073-7086. https://doi.org/10.3168/jds .2018-16130.

Malmuthuge, N., Y. Chen, G. Liang, L. A. Goonewardene, and L. L. Guan. 2015. Heat-treated colostrum feeding promotes beneficial bacteria colonization in the small intestine of neonatal calves. J. Dairy Sci. 98:8044-8053. https://doi.org/10.3168/jds.2015-9607.

Malmuthuge, N., and L. L. Guan. 2017. Understanding the gut microbiome of dairy calves: Opportunities to improve early-life gut health. J. Dairy Sci. 100:5996-6005. https://doi.org/10.3168/jds 2016-12239.

McGrath, B. A., P. F. Fox, P. L. H. McSweeney, and A. L. Kelly. 2016. Composition and properties of bovine colostrum: A review. Dairy Sci. Technol. 96:133-158. https://doi.org/10.1007/s13594 $-015-0258-\mathrm{x}$

McGrath, J. J. 2016. Accelerated pre-weaning growth rates in dairy calves: Do antioxidants have a place? Anim. Prod. Sci. 56:12751284. https://doi.org/10.1071/AN15310.

NRC. 2001. Nutrient Requirement of Dairy Cattle. 7th rev. ed. Natl. Acad. Sci., Washington, DC.

Patel, M. S., M. Srinivasan, and S. G. Laychock. 2009. Metabolic programming: Role of nutrition in the immediate postnatal life. J. Inherit. Metab. Dis. 32:218-228. https://doi.org/10.1007/s10545 $-008-1033-4$

Pazoki, A., G. R. Ghorbani, S. Kargar, A. Sadeghi-Sefidmazgi, J. K. Drackley, and M. H. Ghaffari. 2017. Growth performance, nutrient digestibility, ruminal fermentation, and rumen development of calves during transition from liquid to solid feed: Effects of physical form of starter feed and forage provision. Anim. Feed Sci. Technol. 234:173-185. https://doi.org/10.1016/j.anifeedsci.2017 .06 .004 .

Pempek, J. A., L. R. Watkins, C. E. Bruner, and G. G. Habing. 2019. A multisite, randomized field trial to evaluate the influence of lactoferrin on the morbidity and mortality of dairy calves with diarrhea. J. Dairy Sci. 102:9259-9267. https://doi.org/10.3168/jds 2019-16476.

Romano, J., J. D. Kromrey, J. Coraggio, J. Skowronek, and L. Devine. 2006. Exploring methods for evaluating group differences on the 
NSSE and other surveys: Are the $t$-test and Cohen's $d$ indices the most appropriate choices? Pages 14-17 in Annual Meeting of the Southern Association for Institutional Research, Arlington, VA.

Sadri, H., B. Getachew, M. H. Ghaffari, H. Hammon, J. SteinhoffWagner, and H. Sauerwein. 2020. Short communication: Plasma concentration and tissue mRNA expression of haptoglobin in neonatal calves. J. Dairy Sci. https://doi.org/10.3168/jds.2020-18218. In press.

Scheuer, B. H., Y. Zbinden, P. Schneiter, L. Tappy, J. W. Blum, and H. M. Hammon. 2006. Effects of colostrum feeding and glucocorticoid administration on insulin-dependent glucose metabolism in neonatal calves. Domest. Anim. Endocrinol. 31:227-245. https:// doi.org/10.1016/j.domaniend.2005.11.004.

Snodgrass, D. R., J. Stewart, J. Taylor, F. L. Krautil, and M. L. Smith. 1982. Diarrhea in dairy calves reduced by feeding colostrum from cows vaccinated with rotavirus. Res. Vet. Sci. 32:70-73. https://doi.org/10.1016/S0034-5288(18)32440-8.

Tyler, J. W., D. D. Hancock, S. M. Parish, D. E. Rea, T. E. Besser, S. G. Sanders, and L. K. Wilson. 1996. Evaluation of 3 assays for fail- ure of passive transfer in calves. J. Vet. Intern. Med. 10:304-307. https://doi.org/10.1111/j.1939-1676.1996.tb02067.x.

Van Soest, P. J., J. B. Robertson, and B. A. Lewis. 1991. Methods for dietary fiber, neutral detergent fiber, and nonstarch polysaccharides in relation to animal nutrition. J. Dairy Sci. 74:3583-3597. https://doi.org/10.3168/jds.S0022-0302(91)78551-2.

Wheeler, T. T., A. J. Hodgkinson, C. G. Prosser, and S. R. Davis 2007. Immune components of colostrum and milk-A historical perspective. J Mammary Gland Biol. Neoplasia. 12:237-247. https: //doi.org/10.1007/s10911-007-9051-7.

Yang, M., Y. Zou, Z. H. Wu, S. L. Li, and Z. J. Cao. 2015. Colostrum quality affects immune system establishment and intestinal development of neonatal calves. J. Dairy Sci. 98:7153-7163. https://doi .org/10.3168/jds.2014-9238.

Zhang, L., S. Boeren, J. A. Hageman, T. van Hooijdonk, J. Vervoort, and K. Hettinga. 2015. Bovine milk proteome in the first 9 days: Protein interactions in maturation of the immune and digestive system of the newborn. PLoS One 10:e0116710. https://doi.org/10 .1371/journal.pone.0116710. 